In addition to accumulating disproportionate amounts of isotopes, the foetus may also be more sensitive to their damaging effects. This has been found to be true for exposure to external sources of radiation. Even low doses may induce developmental disorders or malignant changes in embryos. Doses of 3-5 rads given to pregnant

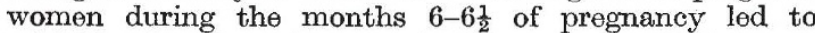
a highly significant increase in the presence of aberrantcolour sectors in the iris of the new-born children. Although this abnormality is entirely harmless, its increase after such low doses indicates the unusually high sensitivity of embryonic tissue. At the time of this report, the question whether maternal irradiation during gestation may cause leukæmia of the child was still under debate. Meanwhile, a recent investigation by MacMahon ${ }^{4}$ supports Alice Stewart's findings. The increased risk to the child of developing leukæmia or other forms of cancer after irradiation in utero has been estimated as 40 per cent. Whether there exists a threshold dose for the production of leukæmias and other malignancies in adults is still an unsolved question. Shortening of life-span has been proved for animals and is considered probable also for man.

The genetical risk is expressed in terms of the "genetically significant dose", that is, the average gonad dose weighted by the expected number of children. The newly recognized chromosomal abnormalities due to non-disjunction, occasionally to translocation, have been included among genetically caused abnormalities. It is estimated. that about 1 per cent of all new-born carry some such chromosomal abnormality, while another I per cent suffer from some harmful trait with clear genetical basis (mainly a dominant autosomal gene). To this are added 4 per cent suffering from developmental malformations and serious constitutional disorders, including mental illness, the hereditary basic of which is not clearly understood. The overall estimate of 6 per cent borm with some hereditary defect is a minimal figure for "it is generally accepted that there is a genetic component in much, if not all, illness". The possibility that some harmful traits may be maintained not through mutation pressure but through heterozygous advantage is considered as applying mainly to localized areas with special environmental conditions. The general frequency of such traits is considered to be exceedingly low. This is important because the frequency of this type of mutation is more or less independent of the amount of radiation received. The members of the Committee, as indeed all geneticists, consider it as "reasonably certain that the overwhelming majority of newly arising mutations have detrimental consequences and that, if beneficial mutations arise at all, the frequency of their occurrence is so low as to be unlikely to offset the burden occasioned by the harmful ones".

There is evidence from recent work on mice and, it should be added, from very old work on Drosophila that chromosomal abnormalities due to non-disjunction are increased by $\mathrm{X}$-rays. For gene mutations, the linear doseeffect relationship has now been established down to doses of $8.5 \mathrm{r}$. in bactoria and $5 \mathrm{r}$. in Drosophila. Tho absence of a threshold for the genetical effects of radiation, which is strongly indicated by these findings, is in no way in- validated by the fact that the absolute amount of damage from a given dose of radiation varies with a number of factors: type of radiation, rate of delivery, type of genetical change scored, type of exposed tissue, degroe of oxygenation as well as various other environmental and physiological conditions. In mice, dose-rate (or intensity of delivery) influences mutation frequeney in immature germ cells but not in spermatozoa, chronic radiation at $8.5 \times 10^{-3} \mathrm{r}$./min being less effective by a factor of about 4 than acute radiation at $90 \mathrm{r} . / \mathrm{min}$. There is, however, no reason to suppose that lowering the dose-rate even more would result in a further decrease of mutation frequency; intensities of $8.5 \times 10^{-3} \mathrm{r}$. $/ \mathrm{min}$ and $1 \times 10^{-3}$ r./min had the same effect. Estimates of actual genetical risks are again expressed by the "doubling dose", that is, the dose that, if present as a permanent background, would double the present burden of hereditary defects. While the 1958 report suggests a doubling dose between 10 and 100 rads, with 30 as the most probable value, it is now estimated that, for acute radiation, the combined value for both sexes is somewhat lower than 30 rads but not less than 15, while for chronic radiation the most probable value is 100 rads or possibly more. Since results with Drosophila suggest a 2 per cent dominance of lethals and semi-lethals, most of the impact of a permanent doubling dose would be felt in about 50 generations. Some, or perhaps most, of this dominant damage may be expressed as an increased death-rate in early life; in experiments on mice, the offspring of irradiated parents had a higher mortality than control animals during the early part of life.

In its concluding remarks, the Committee states: "There should be no misunderstanding about the reality of genetic damage from radiation. Although individual mutations vary greatly in their effect, there is no doubt that any increase in mutation is harmful". "The exposure of mankind to radiation from increasing numbers of artificial sources, including the world-wide contamination of the environment with short- and long-lived radionuclides from weapons tests, calls for the closest attention, particularly because the effects of any increase in radia. tion exposure may not be fully manifested for several decades in the case of somatic disease, and for many generations in the case of genetic damage." "The Committee therefore emphasizes the need that all forms of unnecessary radiation exposure should be minimized or avoided entirely, particularly when the exposure of large populations is entailed; and that every procedure involving the peaceful uses of ionizing radiation should be subject to appropriate immediate and continuing scrutiny in order to ensure that the resulting exposure is kept to the minimum practical level." "As there are no effective measures to prevent the occurrence of harmful effects of global radioactive contamination from nuclear explosions, the achievement of a final cessation of nuclear tests would benefit present and future generations of mankind."

\section{Auerbach}

${ }^{1}$ Auerbach, C., Nature, 182, 1543 (1958).

- Bellefenille, P. de, Acta Rad., 56, 65, 145 (1961).

Bender, M. A., and Gooch, P. C., Rad. Res., 16, 44 (1962).

- MacMahon, B., J. Nat. Cancer Inst., 28, 1173 (1962).

\title{
THE INTERNATIONAL BRAIN RESEARCH ORGANIZATION
}

\author{
BY PROF. H. WAELSCH \\ Columbia University, New York, N.Y.
}

$\mathrm{T}$ HE International Brain Research Organization (IBRO) was founded under the auspices of Unesco in response to the demand from scientists of different disciplines from many countries for the creation of an organization on a world-wide scale for the better mobiliza- tion and utilization of scientific resources of research on the brain. Although details of its short history may be found in the IBRO Bulletin (I, No. 1; 1962) it may be recalled here that the creation of the Organization stems directly from a resolution passed by the members of the 
International Colloquium on Electroencephalography of Nervous Activity held in Moscow, during October 1958. The resolution expressed the conviction that there was a great need for a continuing, international and interdisciplinary organization for the promotion of brain research. A delegation from the colloquium presented the resolution to Unesco and at its tenth session, in 1958, the General Conference of Unesco recommended that its responsibility in the field of natural sciences be extended to brain research. Later, the Council for International Organizations of Medical Sciences was charged with the task of drawing up for Unesco a complete plan of action.

A study group at Unesco House in Paris, in Oetober 1959 , formulated the main outlines of the organization to be named the Interdisciplinary Brain Research Organization, a name later changed to the International Brain Research Organization. Elected compilers drew up lists of scientists to serve on seven international panels, corresponding to those disciplines most directly concerned with brain research. More than 250 men of science, in more than 30 countries, were invited to join the different panels and to elect delegates to represent their respective disciplines at the inaugural meeting of the Central Committee.

The inaugural meeting of the Central Committee of the International Brain Research Organization, organized by the Executive Secretary of the Council for International Organizations of Medical Sciences, Dr. J. Delafresnaye, was held at Unesco House in Paris, in October 1960. It was attended by the elected representatives of the seven scientific panels of the International Brain Research Organization and by representatives from other organizations. These panels were as follows: neuroanatomy, neurochemistry, neuroendocrinology, neuropharmacology, neurophysiology, behavioural sciences, neurocommunications and biophysies. It was decided that the International Brain Research Organization should be established as an iridependent, non-governmental, international organization, incorporated in a country which would provide it with freedom of action anywhere in the world and with authority to engage in joint programmes with Unesco.

During the first two years of its existence the International Brain Research Organization, through the efforts of its first executive secretary, Prof. H. H. Jasper, took shape as an international organization (incorporated in Canada) for the support and devolopment of interdisciplinary research in brain sciences. In addition to many officials of Unesco and members of national and international scientific organizations who put their experience and advice at its disposal, the International Brain Research Organization has from its inception benefited from the interest and counsel of René Maheu, director-general of Unesco, and Prof. V. Kovda, the director of the Department of Natural Sciences of Unesco.

At the last meeting of the Central Council in February 1962, the International Brain Research Organization represented 578 elected members distributed ovor the seven original panels, originating from 38 countries. The Central Council, the governing body of the Organization, is composed of eighteen elected delegates and a corresponding number of alternates and seven members-atlarge. The delegates have a staggered tenure of four years and they elect, for two-year terms, the Executive Committee (at present, P. K. Anokhin, A. Fessard, G. W. Harris, H. W. Magoun, W. A. Rosenblith, J. Szentagothai, and alternates, D. Bovet, V. Chernigovsky and R. Jung; the honorary executive secretary, H. Waelsch; the honorary deputy executive secretary, P. C. Dell; and the honorary treasurer, W. A. Rosenblith). The deputy executive secretary is at the same time responsible for the liaison with Unesco.

In order to implement the aims of the International Brain Research Organization and to advise the Executive
Committee, a number of sub-committees were established and the scope of the Organizations' activities will become evident from a description of these committees.

(1) The Sub-committee on History of Brain Sciences, with $H$. W. Magoun as chairman, organizes its meetings in association with International Congresses in different fields of neurobiology; it collocts and displays historical material and considers the translation and re-publication of certain classical works in brain sciences with contemporary commentaries. It will establish a centre for these activities, probably in the Division of Medical History of the University of California at Los Angeles. In September 1962, an international symposium on "The Development of Neurophysiology in Continental Europe in the 18th and 19th Centuries" was held in Münster (Westphalia) under the sponsorship of the International Brain Research Organization.

(2) The Sub-committee on Publications and Scientific Meetings, under the chairmanship of R. W. Gerard, is participating in the preparation of the IBRO Bulletin and assumes the editorial responsibility for publications sponsored by the International Brain Research Organization or resulting from the Organization's activities. This sub-committee is also responsible for the organization of international interdisciplinary symposia under the sponsorship of the International Brain Research Organization, with the restriction that only one symposium per year may be organized and supported by the International Brain Research Organization itself. Of symposia already held under the sponsorship or co-sponsorship of the International Brain Research Organization, there may be mentioned the colloquium on "Brain Mechanisms: Specific and Unspecific Mochanisms of Sensory-motor Integration" (organized by G. Moruzzi) held in September 1961 at the Physiological Institute of the University of Pisa, and the symposium on "Information Processing in the Nervous System" (organized by R. W. Gerard) hold in conjunction with the International Congress of Physiological Sciences in Leyden, in September 1962.

(3) The Sub-committee on Education, under the chairmanship of J. Elkes, is organizing at the present time visiting regional seminars in various countries on subjects in which the local mon of science have a particular interest. These seminars should serve to underscore some aspects of brain sciences not strongly developed in the host country, or to orient the local men of science in some particular aspect of the field of their interest. A visiting team of up to fifteen men of science and a local audience of not more than fifty colleagues is considered the optimal size for the regional seminars, an essential part of which are laboratory demonstrations and presentations of the men of science of the host country. The first visiting regional seminar is to be held in Warsaw, during May 6-24, 1963, with neuropsychopharmacology as its subject. Invitations for the organization of visiting seminars have been received from India, Hungary, Italy and Israel.

(4) The Sub-committee on Grants and Fellowships, with $\mathrm{V}$. Longo as chairman, is working in close co-operation with the International Exchange Service of Unesco in the administration of a joint fellowship programme. The International Brain Research Organization has agreements with seventeen countries which have offered about thirty fellowships in the institutes of their respective academies and other institutions. These fellowships include subsistence for the fellow in the host country but not funds for travel, which are the joint responsibility of the International Brain Research Organization and Unesco. In addition, there are available International Brain Research Organization/Uneseo fellowships which include not only support for travel but also a maintenance allowance for the Fellow in the institution where he is accepted. A further activity of this committee is concerned with the support of inter-disciplinary research teams in order to facilitate the collaboration of senior men of science of different disciplines from various countries. 
Guide lines for applications for fellowships have been established and are available at the International Brain Research Organization's Secretariat, Unesco House, Paris; a number of International Brain Research Organization fellowships as well as researeh teams organized by the International Brain Organization are already in operation.

Certain projects are assignod to ad hoc committees or are the direct responsibility of the Secrotariat. Into the first group falls the preparation of a survey of manpower and laboratory facilities in brain sciences. This projoct is under the guidance of Dr. H. H. Jasper, with Dr. Stella Doignan as survey officer, and will, in time, compile a directory of men of science working in the various disciplines of brain sciencos as well as of the laboratories available to them. A questionnaire with detailed inquiries as to the scientific intorests, accomplishments and laboratory facilities are boing sont out to all members of the International Brain Research Organization. This survey is essential for the operation of the research team and fellowship programmos and for many other activities of the International Brain Research Organization. Moreover, the Secrotariat has been given the responsibility for the preparation of a hand-took on growth and development of the nervous system, which was considered by tho Central Couneil an essential and primary task for the stimulation of research in this field. A planning session in March 1962, under the chairmanship of Dr. L. Floxner, in co-operation with the World Health Organization and the Council for International Organizations of Medical Sciences was held in Geneva. The Central
Council has also expressed great interest in the subject of Brain Mechanisms of Learning and Memory.

In addition to its affiliation with Unesco as a nongovernmental agency on a consultative basis, the International Brain Research Organization has official relations with the World Health Organization and various other international organizations. The presonce of the representatives of these various international bodies and unions at tho meetings of the Central Council has been greatly appreciated and found to bo of great use to the International Brain Research Organization.

In addition to the subvention by the Department of Natural Sciences of Unesco, the major support for specific projects, such as the regional seminars, symposia and the world survey, has come from the U.S. Public Health Service through international grants. Funds have also been provided for specific purposes by tho National Science Foundation and the National Aeronautic and Space Administration. In addition, private individuals interested in brain sciences have contributed to the unassigned funds of the International Brain Researeh Organization.

Detailed information about the objectives and activities of tho International Brain Research Organization may bo found in the IBRO Bulletin, published several times during the year by the Secretariat. Information may also be obtained directly from the International Brain Research Organization's Secretariat at Unosco House, Place de Fontenoy, Paris. The Secretariat would appreciate any suggostions for the further development and implementation of international interdisciplinary brain research.

\section{PLACE OF TAXONOMY IN THE TEACHING OF BIOLOGY}

\section{A} SYMPOSIUM on the above subject was organized by the Systematics Association in the Univorsity of Birmingham, by invitation of Prof. J. Heslop-Harrison, on January 26.

Prof. J. G. Hawkes (University of Birmingham) pointed out that, up to about eighty years ago, taxonomy comprised the whole of botany, but that from then until the mid-thirties it suffered a decline, being largely replaced by the nower disciplines of plant physiology, ccology and genetics. At the present time, taxonomic teaching and research have come back, to occupy a place of importance equal to those other disciplines.

The place of taxonomy in a botany course must depend on how it is taught and on the interests of the lecturer. Most teachers have now moved away from giving descriptions of one family after another. It is necessary now to show students something of the great diversity within the plant kingdom, yet they cannot be expected to learn more than a fraction of this in a three-year course. Consequently, they must be given a reasonablo knowledge of the British flora, and shown the theoretical bases of taxonomic research, and their taxonomic investigations linked with other aspects of botany.

The links between taxonomy and plant morphology and anatomy are obvious. No less important is the relation between taxonomy and plant ecology, for one must be able to identify the plants with which ono is working in the field. Discussion of ecological and geographical barriers in species formation gives the student a background of ecological thought to apply whon examining plants in field or herbarium.

Taxonomic teaching should link closely with genetics and eytology, since these investigations can show by experiment how plants are rolated to each other, and how they are evolving. Attention should be directed to cytological criteria in classification. Chromosome investigations in natural and artificial hybrids can be most stimulating, and should include examples from eultivated plants, where cytologists and plant breeders have been able to elucidate the evolutionary relations of cultivated to wild species. Though relatively few plant species have been investigated genetically, enough knowledge exists to provide an understanding of tho different sorts of variation. Many geneticists have gone ovor to the field of experimental taxonomy, yet would be surprised to be told they were engaged in taxonomic research.

Too much stress should not be laid on nomenclature, though this aspect must not be wholly neglected, and can be linked with the history of botanical thought. The value of biomotrical and statistical investigations needs no stressing, and these can profitably be pursued by students who are mathematically inclined. Latterly it has become more and more possible to draw on comparative invostigations in plant biochomistry and serology to holp in classifying both species and higher categories. Thus, students can use the taxonomic approach to fit otherwise unrelated information into a unifying framowork of ideas. Without such a focal point, work in other fields is very liable to be incorrectly assessed or invalidated.

In conclusion, P'rof. Hawkes gave his ideas on how taxonomy might be taught in sixth forms in schools, and an outline of the taxonomy course ho himself has used in Birmingham.

Prof. O. W. Richards (Imperial College of Science and Technology) reminded his audionce of the varied opinions as to how zoology should be taught and said his viow was that not all students should recoive the same type of training, but that the greater the variety of course available the better it would be. However, in a programmo concerned mainly with functions and processes common to many groups, there was need of a short course in taxonomy, to inculcate an understanding of the variety of creatures, whereas in ono organizod around the ideas of classification and evolution there was less nood for formal instruction 